\title{
Ekosistem Bisnis Wisata Halal dalam Perspektif Maqasid Syariah (Halal Tourism Business Ecosystem in the Maqasid Syariah Perspective)
}

\author{
Lucky Nugroho ${ }^{1 *}$, Wiwik Utami ${ }^{2}$, Caturida Meiwanto Doktoralina ${ }^{3}$ \\ ${ }^{1}$ Universitas Mercu Buana, Indonesia, ${ }^{2}$ Universitas Mercu Buana, Indonesia, ${ }^{3}$ Universitas Mercu Buana, Indonesia
}

The purpose of this study is to provide input to stakeholders related to the halal tourism business ecosystem strategy in sharia perspective. This research is a conceptual paper using qualitative methods supported by literature studies to explain phenomena that are conducted with the approval of research questions (1) What is discussed with Maqasid Sharia ?; (2) What is meant by the business ecosystem strategy ?; (3) How to improve Indonesia's tourism competitiveness through the halal tourism business ecosystem? In accordance with the government's goal, which is to make Indonesia the center of Islamic finance and the potential acquisition of Indonesian Muslims, the halal tourism business ecosystem can be one of the priority strategies of the government's program to attract foreign tourists coming to Indonesia through purchasing assistance and infrastructure based on sharia maqasid principles.

Keywords: Halal Tourism Ecosystem, Maqasid Syariah

OPEN ACCESS

ISSN 2503-3077 (Online) (online) ISSN 2503-3077 (print)

${ }^{*}$ Correspondence: Lucky Nugroho

lucky.nugroho@mercubuana.ac.id

Received: 21 August 2019 Accepted: 21 September 2019 Published: 30 October 2019

Citation:

Nugroho L, Utami $W$ and Meiwanto Doktoralina C (2019) Ekosistem Bisnis Wisata Halal dalam Perspektif

Maqasid Syariah (Halal Tourism

Business Ecosystem in the Maqasid Syariah Perspective).

Perisai : Islamic Banking and

Finance Journal. 3:2.

doi: 10.21070/perisai.v3i2.1964

Tujuan dari penelitian ini adalah memberikan masukkan kepada para pemangku kepentingan terkait dengan strategi ekosistem bisnis wisata halal dalam perspektif syariah. Penelitian ini adalah konspetual paper dengan menggunakan metode kualitatif yang didukung kajian-kajian pustaka untuk menjelaskan fenomena yang terjadi dengan pembatasan pertanyaan penelitian (1) Apa yang dimaksud dengan Maqasid Syariah?; (2) Apa yang dimaksud dengan strategi ekosistem bisnis ?; (3) Bagaimana meningkatkan daya saing pariwisata di Indonesia melalui ekosistem bisnis wisata halal?. Sesuai dengan tujuan pemerintah, yaitu menjadikan Indonesia sebagai pusat keuangan syariah dan potensi mayoritas Muslim Indonesia, maka ekosistem bisnis wisata halal dapat dijadikan salah satu strategi prioritas program pemerintah untuk menarik wisatawan mancenagera datang ke Indonesia melalui peningkatan layanan dan infrastruktur yang berlandaskan prinsip maqasid syariah. 


\section{PENDAHULUAN}

Saat ini jumlah populasi umat Islam di dunia telah mencapai 1,7 miliar jiwa, yaitu sama dengan seperempat (25\%) jumlah penduduk di dunia yang nota bene menduduki peringkat kedua setelah umat Nasrani, bahkan diperkirakan jumlah tersebut akan semakin meningkat dikarenakan jumlah rasio kelahiran keluarga Muslim adalah 2,7 sedangkan keluarga Nasrani memiliki rasio 2,2 Huda (2018). Umat Muslim ini tersebar di seluruh penjuru negara di dunia, meskipun sebagian besar masyarakat mengira negara timur tengah merupakan pusatnya agama Islam, namun porsi total penduduk dari negara timur tengah ternyata hanya $15 \%$ dari populasi muslim di dunia. Populasi terbesar Muslim terdapat pada negaranegara di benua Asia, yaitu mencapai 59,69\% dari seluruh populasi muslim di dunia.

Indonesia merupakan negara dengan jumlah penduduk Muslim terbesar di dunia, yaitu sebesar 209,1 juta sehingga $12,65 \%$ penduduk muslim berada di Indonesia. Tentunya kondisi ini harus dapat dimanfaatkan oleh pemerintah sebagai peluang menempatkan Indonesia sebagai pusat kebudayaan dan bisnis Islam. Islam di turunkan oleh Allah SWT sebagai agama yang memberi rahmat bagi seluruh umat manusia atau Islam sebagai agama Rahmatan lil Alamin yang tertuang dalam Q.S Al- Anbiyaa ayat 107 yang artinya "Dan tiadalah Kami mengutus kam. Sejalan dengan kebutuhan umat Muslim tersebut, maka pemerintah wajib menunjang kebutuhan dari ummat muslim tersebut dalam bentuk sarana dan prasarana serta perangkat regulasi yang saling mendukung guna terimplementasinya kehidupan sehari-hari umat muslin sesuai dengan syariat Islam yang selanjutnya disebut dengan Halal Bisnis Ekosistem.

Indoensia merupakan negara yang memiliki banyak tujuan wisata yang menarik bagi para wisatwan baik lokal maupun manca negara. Dengan banyaknya tempat wisata yang menarik untuk dikunjungi, maka pariwisata dapat dijadikan salah satu alternatif meningkatkan pendapatan negara. Pencapaian kinerja sektor pariwisata per Desember 2018 (BPS, Februari 2019), menunjukkan hasil yang positif dimana terdapat kenaikan pengunjung wisatawan mancanegara sebesar $12,58 \%$ apabila dibandingkan dengan tahun sebelumnya. Sesuai dengan peningkatan jumlah persentase kunjungan wisatawan mancanegara tersebut, maka jumlah wisatawan mancanegara sepanjang tahun 2018 menjadi 15,81 juta kunjungan sedangkan tahun sebelumnya hanya 14,04 juta kunjungan. Selanjutnya apabila diklasifikasikan negara asal dari wisatawan mancanegara ( wisman ) tersebut, maka lima besar negara pengunjungnya (63,22\% wisman ) yang antara lain adalah Singapura, Malaysia, Timor Leste, Tiongkok dan Australia.

$\mathrm{N}$ egara Malaysia menduduki peringkat kedua kunjungan wisatawan mancanegara ke Indonesia yang notabene mayoritas mereka adalah Muslim. Dengan demikian, peningkatan jumlah wisman tersebut dapat mendongkrak pendapatan bisnis perhotelan melalui peningkatan tingkat penghunian kamar (TPK), pada tahun 2017 tingkat penghunian kamar mencapai 59,53\% sedangkan pada tahun 2018 menjadi 59,75\% BPS (2019). Peningkatan wisman tersebut juga merupakan hasil dari jerih payah promosi yang dilakukan oleh Kementerian Pariwisata melalui Promises Branding "Wonderful Indonesia ” secara besar-besaran di London pada akhir tahun 2016 yang ditempelkan di Black Cab Taxi Nugroho (2017). Selain itu, Kementerian Pariwisata pada tahun 2016 telah mampu meningkatkan peringkatnya dari rangking 50 ditahun 2015 menjadi rangking 42 menurut Forum (2017) . Namun demikian Pemerintah tetap harus melakukan inovasi dan pembaharuan untuk meningkatkan layanan kualitas pariwisata Indonesia dengan keunikan yang dimiliki, karena apabila dibandingkan dengan negara ASEAN lainnya, Indonesia masih tertinggal peringkatnya. Adapun secara global peringkat tujuan wisatawan negara-negara di ASEAN adalah sebagai berikut : Singapura (13); Malaysia (26); Thailand (34); Indonesia (42); Sri Lanka (64); Vietnam (67); Filipina (79); Laos (94); dan Kamboja (101).

Selanjutnya untuk menghadapi persaingan sektor pariwisata tersebut, maka diperlukan adanya perubahan strategi untuk dapat meraih pasar yang sebelumnya fokus pada product-oriented dan consumer-oriented menjadi business ecosytem -oriented. Sesuai dengan fenomena di atas, maka terdapat kebutuhan untuk meningkatkan daya saing pariwisata Indonesia melalui sumber daya dan keunikan yang dimiliki sehingga diperlukan suatu ekosistem bisnis halal yang menjadi salah satu strategi meningkatkan daya saing wisata. Selanjutnya rumusan masalah pada artikel ini di batasi dengan pertanyaan penelitian sebagai berikut:

- Apa yang dimaksud dengan Maqasid Syariah?

- Apa yang dimaksud dengan strategi ekosistem bisnis?

- Bagaimana meningkatkan daya saing pariwisata di Indonesia melalui ekosistem bisnis wisata halal?

\section{METODOLOGI}

Penelitian ini bertujuan untuk memberikan kontribusi kepada para pemangku kepentingan (stakeholder) untuk membuat kebijakan yang sesuai dengan kondisi dan potensi pariwisata serta keinginan pemerintah menjadikan Indonesia sebagai Pusat Internasional Keuangan Islam di dunia. Lebih lanjut, dalam rangka menjawab pertanyaan penelitian, maka metoda yang digunakan dalam artikel ini adalah kualitatif dengan menggunakan pendekatan kajian pustaka dan data-data yang bersumber dari penelitian-penelitian terdahulu yang terkait dengan implementasi pariwisata halal. Adapun pengumpulan data, peneliti menggunakan data sekunder yang berasal dari jurnal ilmiah dan sumber-sumber media elektronik yang diterbitkan oleh institusi resmi. Selanjutnya mekanisme metodologi pada artikel ini adalah sebagai berikut:

- Mengetahui konsep dari maqasid syariah berdasarkan penelitian-penelitian terdahulu;

- Mengetahui konsep dari strategi ekosistem bisnis berdasarkan penelitian-penelitian terdahulu;

- Menghubungkan konsep dari maqasid syariah dengan strategi ekosistem bisnis wisata halal dalam rangka meningkatkan daya saing pariwisata di Indonesia.

\section{HASIL DAN PEMBAHASAN}

Hasil dan pembahasan pada artikel ini merupakan kajian literatur atau pustaka dan merupakan konsep strategi yang 
dapat digunakan oleh stakeholder untuk menjadikan Indonesia sebagai Pusat Keuangan Islam melalui implementasi Ekosistem Bisnis wisata halal. Dengan demikian hasil dan pembahasan artikel ini kami sesuaikan dengan pertanyaan penelitian penelitian.

\section{Maqasid Syariah}

Al-Qur' an merupakan pegangan hidup bagi muslim dan merupakan doktrin universal yang meliputi seluruh aspek kehidupan manusia Zuhdi and Harfin (2017). Berikut adalah mekanisme peran dari Al-Qur' an, hadist dalam kehidupan ummat:

[Figure 1 about here.]

Sumber : Sukmadilaga and Nugroho (????).

Merujuk pada Gambar 1 di atas, maka mekanisme untuk mewujudkan social wellbeing atau kesejahteraan sosial, maka diperlukan proses mulai dari Allah menurunkan Al-Qur' an di bumi untuk dijadikan pedoman oleh manusia dalam menjalankan hidupnya. Namun demikian Al- Qur,an harus dilengkapi oleh hadist, dimana Muhammad sebagai utusan atau Rasul Allah melalui perkataan, perbuatan dan perilakunya yang berikutnya tertulis dalam hadist ketika Rasul telah wafat. Selanjutnya permasalahan banyak timbul ketika Rasul, Sahabat, Tabi'in-Tabi'in wafat dikarenakan sudah tidak terdapat lagi tempat bertanya sebagai sumber kebenaran. Dengan demikian peran ijtihad ulama sangat penting alam mencari solusi permasalahan yang terdapat dalam kehidupan manusia melalui proses ijtihad. Proses ijtihad adalah proses pengambilan keputusan yang dilakukan oleh para cendekiawan muslim sesuai dengan kapasitas dan kemampuannya untuk saling bertukar pikiran untuk mencari solusi dalam rangka menyelesaikan masalah dengan bersumber dari Al-Qur' an dan hadist. Semua elemen seperti Al-Qur ' an, hadist dan ijtihad ulama harus diimplementasikan dalam kehidupan sehari-hari umat dengan menggunakan ilmu pengetahuan, etika, moral dan akhlak sehingga terciptalah kehidupan masyarakat madani atau menurut Majid (2000) dan Frinaldi and Embi (2011) pengertian dari masyarakat madani adalah masyarakat plural yang saling menghormati dan menghargai serta memiliki peradaban yang tinggi.

Menurut Nugroho et al. (2017) dan Karim (2017) Karim (2017) panduan dalam kehidupan muslim adalah adanya prinsip tauhid yang artinya semua kebenaran dan aturan berasal dari Allah SWT ( "tiada Tuhan selain Allah") sehingga Islam merupakan agama yang sempurna yang mengatur seluruh tidak hanya kehidupan manusia tetapi juga terkait dengan alam semesta ( Tauhid String Relationship -TSR). Dengan demikian menurut Choudhury and Alam (2013), implementasi dari prinsip tauhid adalah melaksanakan perintah Allah SWT dan menjauhi larangan -Nya. Apabila prinsip tauhid diformulasikan dalam sebuah persamaan menjadi sebagai berikut:

$(\Omega, \mathrm{s}) \rightarrow^{*} \Theta \rightarrow \Theta \rightarrow \mathrm{x} \Theta \rightarrow \mathrm{W}(\Theta, \mathrm{x} \Theta) \rightarrow \mathrm{N} \Theta \rightarrow(\Omega, \mathrm{s})$

Keterangan:

$\Omega$ : Al-Qur'an

S: Hadist

${ }^{\star} \Theta$ : Ijtihad

$\Theta$ : Ilmu Pengetahuan dan Teknologi $\mathrm{x} \Theta$ : Implementasi dari Iman \& Taqwa serta Ilmu Pengetahuan \& Teknologi

$\mathrm{W}(\Theta, \mathrm{x} \Theta)$ : Maslahat-Kesejahteraan Sosial

$\mathrm{N} \Theta$ : Ilmu Pengetahuan Baru (knowledge-update )

Penjelasan atas formula di atas menurut Choudhury and Alam (2013) dan Nugroho and Husnadi (2017), sumber hukum dan pengetahuan manusia ( pegangan hidup ) untuk diterapkan dalam kehidupan sehari-hari manusia adalah Wahyu dari Allah atau Al-Qur' an. Selanjutnya Allah memberikan contoh pelaksanaan Al-Qur' an $(\Omega)$ tersebut melalui nabi-nabi -Nya dengan ditutup oleh Rasul Muhammad SAW dengan agama yang telah sempurna, yaitu Islam. Nabinabi dan Rasul merupakan contoh nyata dari ayat-ayat yang terdapat dalam Al-Qur' an dalam melaksanakan kehidupan yang ideal untuk mendapatkan kebahagiaan di dunia dan di akhirat. Pada rasul masih hidup, maka segala perkataan, tindakan dan sikap beliau tidak perlu ditulis, karena bisa langsung bertemu dan bertanya kepada Rasul, namun setelah beliau wafat perlu adanya dokumentasi yang dilakukan oleh para Sahabat yang pernah berjumpa dan melihat langsung apa yang dilakukan dan dikatakan oleh Rasul yang tertuang dalam bentuk Hadist, Ijma dan Qiyas (S). Al-Qur' an dan Hadist merupakan pegangan hidup dari manusia dan bersifat kontekstual ( mengikuti perubahan jaman ), sehingga dengan terdapatnya perkembangan dan perubahan jaman maka Al-Qur' an dan Hadist perlu ditafsirkan oleh para ulama-ulama melalui tukar pemikiran dan forum diskusi sehingga terdapat Ijtihad $\left({ }^{*} \Theta\right)$. Selain itu ilmu pengetahuan $(\Theta)$ merupakan unsur penting yang membedakan manusia dengan makhluk ciptaan Allah lainnya. Allah menciptakan manusia yang dilengkapi oleh akal sehingga manusia merupakan ciptaan yang sempurna seperti yang tertuang dalam Q.S At- Tiin Ayat 1-4 "(1) Demi (buah) Tin dan (buah ) Zaitun, (2) demi Gunung Sinai, (3) dan demi negera (Mekkah ) yang aman ini, (4) Sesungguhnya kami telah menciptakan manusia dalam bentuk yang sebaik-baiknya."

Kedudukan ilmu pengetahuan sangat penting dalam kehidupan manusia ( Masruri, 2012).) bahkan wahyu pertama yang diturunkan kepada Nabi Muhammad menyebutkan pentingnya membaca, menulis, dan ilmu bagi manusia tang teruang dalam Q.S Al- Alaq 1-5 “(1) Bacalah dengan (menyebut) nama Tuhanmu yang menciptaka'

Dengan demikian iman dan taqwa-Imtaq $\left(\Omega, \mathrm{S},{ }^{\star} \Theta\right)$ harus diimplementasikan dengan ilmu pengetahuan dan teknologiIptek $(\Theta)$ sehingga terwujudlah implementasi dari Imtaq dan Iptek dalam kehidupan dan aktivitas manusia $(\mathrm{x} \Theta$ ) yang akan memberikan kesejahteraan sosial ( maslahat) bagi umat (W $(\Theta, x \Theta))$. Oleh karenanya menurut Fitrotullah (2013), apabila kesejahteraan sosial telah terwujud maka terciptalah peradaban $(\mathrm{N} \Theta)$ yaitu terciptanya masyarakat yang madani dimana terpenuhinya aspek intelektual ( Tamadun ) dan aspek spiritual ( Tsaqâfah ) pada kehidupan bermasyarakat.

Termasuk dalam memberikan layanan kepada para wisatawan sudah selayaknya pelaku pariwisata di Indonesia dapat mengintegrasikan dengan konsep maqasid syariah sehingga akan memberikan layanan yang baik dan memberikan kesan yang sopan, beretika, bermoral dan berakhlaq Harahap (2014). Pelayanan dengan prinsip maqasid syariah ini bertujuan dalam rangka mendukung program pemerintah menjadikan Indonesia sebagai destinasi wisata halal dunia. Selain itu saat ini berdasarkan data BPS (2019) Malaysia merupakan negara no.2 
wisatawan mancanegara yang datang ke Indonesia sesuai dengan Gambar 2 di bawah ini:

\section{[Figure 2 about here.]}

Sumber: BPS (2019)

Selain itu menurut penelitian terdahulu yang dilakukan oleh Widagdyo (2015) menyatakan bahwa selain dari pelancong atau wisatawan mancanegara muslim yang memiliki jumlah yang signifikan bagi industri pariwisata Indonesia selain Malaysia adalah negara- negara Timur Tengah terutama Saudi Arabia, Uni Emirat Arab dan beberapa negara di kawasan teluk seperti Oman, Qatar, Mesir Kuwat dan Bahrain. Berdasarkan kondisi tersebut, maka sudah selayaknya Indonesia menjadi negara yang memiliki daya tarik khusus bagi wisatawan mancanegara yang berasal dari negara muslim di dunia. Namun demikian bukan berarti dengan adanya destinasi wisata halal, maka wisatawan mancanegara lainnya tidak menjadi prioritas bahkan dengan adanya prinsip maqasid syariah ini wisatawan akan menjadi merasa aman dan nyaman untuk berwisata.

\section{Strategi Ekosistem Bisnis}

Indonesia sebagai negara kepulauan memiliki variasi destinasi wisata yang lengkap. Menurut Undang-undang Nomor 10 tahun 2009 tentang Kepariwisataan Indonesia meliputi:

Pada era globalisasi ini informasi yang tidak terbatas antar negara tentunya memberikan informasi yang lengkap dan menjangkau seluruh negara di dunia. Dampak dari perkembangan informasi di era globalisasi ini meningkatkan pengetahuan dari calon wisatawan terkait dengan tujuan wisata sehingga mereka akan memilih tempat wisata yang sesuai dengan keinginan mereka. Oleh karenaya industri wisata di Indonesia perlu memiliki strategi agar dapat bersaing dalam industri wisata di dunia Sudiarta (2018) .

Persaingan merupakan keniscayaan sehingga para pelaku pasar perlu membuat dan merancang strategi untuk dapat bertahan atau bahkan dapat menguasai pasar. Menurut (Seddon \& Lewis, 2003 Seddon and Lewis (2003) beberapa pengertian strategi menurut porter selama tahun 1996-2001 yang antara lain:

- Tujuan dari strategi adalah untuk memperoleh pengembalian dari investasi jangka panjang yang optimal. Terciptanya nilai ekonomi ( economic values ) ketika pelanggan bersedia membeli suatu produk atau layanan dengan harga yang melebihi biaya produksi dari produk dan layanan tersebut. Porter and Gibbs (2001);

- Strategi yang kompetitif adalah bagaimana berusaha untuk menjadi berbeda Porter (1996);

- Strategi adalah menciptakan suatu posisi perusahaan atau organisasi yang unik dan berharga, dengan menggunakan serangkaian kegiatan atau proses yang berbeda dari rival atau kompetitor Porter (1996);

- Strategi adalah menggunakan seluruh sumber daya secara optimal dalam bersaing Porter (1996);

- Strategi adalah memastikan seluruh elemen dalam perusahaan atau organisasi dapat bersinergi Porter and Gibbs (2001);

- Efektivitas dalam operasional dan strategi memiliki peran penting untuk menciptakan kinerja unggul yang dilakukan oleh seluruh perusahaan atau organisasi dalam mencapai tujuannya, meskipun setiap perusahaan atau organisasi tersebut memiliki cara yang berbeda Porter (1996);

- Efektivitas dalam operasional adalah melakukan kegiatan yang sama akan tetapi memiliki hasil yang lebih baik daripada yang dilakukan pesaing Porter (1996);

- Strategi memerlukan kesinambungan dalam perencanaan atau arah yang ingin dicapai oleh perusahaan atau organisasi Porter and Gibbs (2001).

Selain itu menurut Pearce et al. (2000) strategi bisnis adalah kemampuan perusahaan atau organisasi dalam melakukan analisa lingkungan eksternal perusahaan dan internal perusahaan, melakukan perumusan ( formulasi ) strategi, mengimplementasikan rencana-rencana yang telah direncanakan melalui program kerja untuk mencapai sasaran-sasaran perusahaan, serta melakukan evaluasi yang bertujuan untuk memberikan masukkan atau input dalam pembuatan strategi yang akan datang. Adapun indikator-indikator yang digunakan adalah:

- Selalu memperkenalkan produk baru;

- Menciptakan produk yang berbeda;

- Melakukan riset pasar;

- Mengeluarkan biaya operasional lebih rendah dari pesaing;

- Membuat produk atau jasa dengan biaya yang efesien;

- Mengoptimalkan penggunaan alat dan fasilitas produksi;

- Melakukan analisis biaya;

- Menyediakan peralatan kerja yang menunjang optimalisasi outcome;

- Fokus pada pelanggan tertentu;

- Fokus pada produk tertentu;

- Fokus pada segmen pasar tertentu.

Namun demikian, seiring dengan meningkatnya tingkat persaingan pada saat ini, maka perlu adanya perubahan strategi untuk dapat meraih pasar dengan yang sebelumnya fokus pada product-oriented dan consumer-oriented menjadi business ecosytem -oriented. Menurut ( Iansiti et al., 2004) terdapat banyak perusahaan dan organisasi yang tidak dapat bertahan dalam berkompetisi karena karena mereka tidak melakukan analisa secara menyeluruh terhadap usahanya dikarenakan hany fokus pada aspek tertentu saja atau menggunakan analisa nilai rantai ( value chain ) dari supplier dan distributor saja yang terkait secara langsung dengan perusahaan atau organisasi. Dengan demikian, strategi bisnis ecosytemoriented adalah melakukan analisa atas seluruh aspek yang saling terkait. Saat ini berbagai perusahaan saling berkolaborasi untuk saling melengkapi dalam memproduksi suatu produk yang memiliki kualitas tinggi seperti produk-produk elektronik, bahkan kompetitor pun menjadi bagian dari ekosistem bisnis karena dapat memberikan masukkan dan evaluasi yang bertujuan untuk memperbaiki kinerja di masa yang akan datang. Lebih lanjut, terdapat kesulitan dalam menganalisa ekosistem yang begitu kompleks karena banyak pihak-pihak yang berkepentingan atas aktivitas bisnis suatu perusahaan atau organisasi. Namun demikian, untuk memudahkan melakukan analisa ekosistem bisnis dalam rangka menyusun strategi, maka diperlukan langkah awal mengidentifikasi pihak-pihak yang memiliki hubungan erat dan sangat 
menentukan atas operasional bisnis perusahaan atau organisasi. Terdapat tiga hal yang menjadi pertimbangan dalam mengidentifikasi prioritas dalam ekosistem bisnis perusahaan yang antara lain adalah:

- Produktivitas ( Productivity ), pertimbangan produktivitas adalah aktivitas kerjasama dan kolaborasi dapat meningkatkan kinerja bagi organisasi dan perusahaan ;

- Memperkuat ( Robustness ), pertimbangan kerjasama dan kolaborasi adalah saling melengkapi dan memperkokoh kualitas produk dan layanan sehingga memiliki daya saing

- Menciptakan peluang ( Niche Creation ), pertimbangan kerjasama dan kolaborasi adalah menciptakan peluang melalui inovasi pada bisnis proses maupun bisnis model yang baru sehingga produk dan layanan yang dihasilkan oleh perusahaan atau organisasi berbeda dengan yang terdapat pada saat ini sehingga produk atau layanan tersebut dapat terjual secara optimal di pasar.

\section{Implemetasi Meningkatkan Daya Saing Pariwisata di Indonesia Melalui Ekosistem Bisnis Wisata Halal}

Ecosytem-oriented atau ekosistem bisnis wisata halal adalah elemen-elemen yang mencakup seluruh elemen-elemen seperti pemerintah, masyarakat, pelaku bisnis dan seluruh industri terkait yang mendukung bisnis wisata halal tersebut untuk bersinergi dalam rangka memberikan layanan terbaik kepada para wisatawan yang datang berkunjung ke Indonesia. Seperti diketahui pada Gambar 2 di atas, di ketahui bahwa pengunjung wisatawan mancanegara yang datang ke Indonesia peringkat No.2 adalah Malaysia yang notabene mereka adalah mayoritas muslim dan negara-negara timur tengah memiliki kontribusi yang besar atas pendapatan pariwisata di Indonesia Widagdyo (2015). Oleh karenanya untuk meningkatkan daya saing melalui ekosistem bisnis wisata halal tidak hanya memperbaiki obyek wisata halal saja tetapi harus seluruh elemen yang mendukung wisata halal tersebut termasuk kebutuhan mereka untuk melaksanakan ibadah. Adapun yang diperlukan peningkatan kualitas antara lain sebagai berikut:

- Tedapatnya fasilitas dan layanan akomodasi yang dapat memberikan keamanan dan kenyamanan kepada para wisatawan yang menginap. Selain itu juga harus ditunjang dengan fasilitas perlengkapan dan fasilitas ibadah, menyediakan layanan kepada pengunjung ketika sedang berpuasa dan di bulan ramadhan ( saur dan berbuka ), dan fasilitas lainnya yang membuat wisatawan muslim dapat menjalankan liburan dengan tetap melaksanakan ibadahnya ;

- Tersedianya $\mathrm{f}$ asilitas transportasi yang aman dan nyaman serta disediakannya tempat untuk melaksanakan ibadah di dalam perjalanan menuju tempat tujuan. Selain itu transportasi juga harus ditunjang dengan keberadaan infrastruktur jalan raya, jembatan dan lainnya sehingga menjamin keselamatan dan kenyamanan para wisatawan. Selain itu diperlukan terdapat nya fasiltas pemisahan antara pria dan wanita pada transportasi publik ;

- Media, tempat hiburan dan tempat perbelanjaan juga menjadi ekosistem bisnis wisata halal yang harus dapat mem- berikan promosi dan pemasaran yang menarik wisatawan yang dilengkapi dengan fasilitas ibadah serta kemanan dan kenyamanan. Icon Indonesia sebagai fashion center untuk pakaian muslim juga harus terus diperkuat dengan berbagai internasional event. Bahkan dapat diperkuat dengan pembuktian seperti testimoni para pengunjung yang puas untuk dapat juga dijadikan strategy promosi serta pemasaran yang efektif (experienced marketing-customer);

- Untuk mempermudah para wisatawan untuk memilih obyek wisata yang beragam, maka perlu adanya jasa agen perjalanan, penyelenggara tour yang profesional. Informasi obyek wisata juga harus tersedia di pusat informasi wisata yang terletak di lokasi-lokasi strategis masuknya wisatawan ke setiap daerah di Indonesia ( seperti di Bandara, Pelabuhan, Stasiun Kereta Api dan Terminal Bis);

- Pergi wisata tidak lengkap tanpa adanya kuliner, oleh karenanya pelaku industri makanan dan minuman sebagai pendukung utama mampu memberikan layanan bukan hanya rasa makanan dan minumanya akan tetapi memastikan makanan dan minuman yang dikonsumsi telah memenuhi aspek halal.

Selain itu juga terdapat beberapa kelemahan sektor pariwisata yang perlu diperbaiki yang antara lain:

- Belum terdapatnya sinergi strategis dan kurangnya komitmen dari pemerintah, Tanggung jawab meningkatkan kualitas pariwisata bukan pada kementerian pariwisata tetapi kementerian lain yang terkait untuk memperbaiki kondisi seperti masalah keamanan di daerah ( bebas dari copet dan preman ), membenahi akses transportasi seperti para wisatawan asing akan enggan ke Jakarta yang terkenal dengan macetnya, kecelakaan dan keamanaan penggunaan transportasi ;

- Terbatasnya sistem informasi sehingga informasi obyek wisata di Indonesia masih sangat terbatas untuk dapat diakses oleh wisatawan mancanegara terutama yang menggunakan bahasa internasional ( Inggris );

- Lemahnya keberadaan pelaku ekonomi kreatif untuk mendukung industri Islamic fashion, halal food and drink, dan lain sebagainya yang dapat menarik wisatawan datang berbelanja produk sandang dan pangan buatan Indonesia;

- Selain itu sektor pariwisata di Indonesia yang tergantung pada alam dan iklim sudah seharusnya didukung dengan lingkungan yang bersih dari sampah dan tingkat polusi dikota-kota besar Indonesia yang telah disesaki oleh kendaraan roda empat dan roda dua sehingga menyebabkan para wisatawan menjadi tidak nyaman dan menyebabkan mereka tidak betah untuk tinggal lebih lama lagi.

Berdasarkan hal tersebut, maka untuk meningkatkan daya saing pariwisata di Indonesia terutama ekosistem bisnis wisata halal bukan hanya usaha keras dari salah satu pihak misal kementerian pariwisata, akan tetapi harus bersinergi antar kementerian terkait dan juga seluruh pemangku kepentingan. Sangat disayangkan Indonesia sebagai negara dengan banyaknya tujuan wisata dan potensi muslim terbesar di dunia tidak dapat bersaing dengan banyaknya tujuan wisata dan potensi muslim terbesar di dunia tidak dapat bersaing dengan negara lainnya pada sektor pariwisata. 
Solusi-solusi tersebut tentu sesuai dengan prinsip dari maqasid syariah yang menurut Arafah and Nugroho (2016), Chapra (2008) dan Doktoralina et al. (2018) bahwa Islam memiliki landasan syariah dan menjadi kewajiban setiap muslim untuk mewujudkan keberlanjutan bisnis wisata harus memenuhi kepentingan agama, kepentingan ekonomi, kepentingan sosial dan kepentingan lingkungan. Dengan demikian pelaksanaan prinsip maqasid syariah yang meliputi menjaga agama, menjaga akal, menjaga jiwa, menjaga harta, menjaga keturunan dan menjaga lingkungan dapat dijadikan solusi dalam mengimplementasikan ekosistem bisnis wisata halal.

\section{KESIMPULAN}

Indonesia merupakan negara muslim terbesar di dunia dan pemerintah juga berencana menjadikan Indonesia sebagai pusat keuangan Islam internasional. Salah satu solusi untuk dapat bersaing dengan negara-negara lainnya di dunia adalah menerapkan strategi ekosistem bisnis wisata halal. Adapun pertimbangan-pertimbangannya adalah

- Umat Islam harus melaksanakam agamanya secara totalitas ( kaffah ) dan segala aktivitas bisnis harus berlandaskan maqasi syariah dan juga bersifat universal sehingga bagi wisatawan non muslim akan lebih aman dan nyaman berwisata di Indonesoa ;

- Untuk menyusun suatu strategi persaingan saat ini harus dilaksanakan secara komprehensif tidak lagi dianalisa dari sisi pelanggan ( customer oriented) dan sisi produk ( produk oriented ), akan tetapi secara keseluruhan bisnis sebagai suatu ekosistem ( ecosytem business oriented );

- Konsep dari strategi ekosistem bisnis wisata halal dengan pendekatan maqasid syariah dapat dijadikan solusi bagi stakeholder untuk memajukan bisnis wisata di Indonesia.

\section{REFERENCES}

Arafah, W. and Nugroho, L. (2016). Maqhashid sharia in clean water financing business model at Islamic bank. International Journal of Business and Management Invention 5, 22-32.

BPS (2019).

Chapra, M. U. (2008). Ibn Khaldun's theory of development: Does it help explain the low performance of the present-day Muslim world? The Journal of SocioEconomics 37, 836-863.

Choudhury, M. A. and Alam, M. N. (2013). Corporate governance in Islamic perspective. International journal of Islamic and Middle Eastern finance 6, 180-199.

Doktoralina, C. M., Anggraini, S. D., and Melzatia, S. (2018). The Importance of Sustainability Reports In Non-Financial Companies. Jurnal Akuntansi 22, 368384.

Fitrotullah, M. R. (2013). Konstruk Filsafat dan Agama dalam Bingkai Peradaban Islam

Forum, W. E. (2017). The Travel \& Tourism Competitiveness Report 2017. http://www3.weforum.org/docs/ $\mathrm{WEF}_{T} T C R_{2} 017_{w} e b_{0} 401 . p d f$.

Frinaldi, A. and Embi, M. A. (2011). Pengaruh Budaya Kerja Etnik Terhadap Budaya Kerja Keadilan dan Keterbukaan PNS dalam Membangun Masyarakat Madani dan Demokrasi (Studi Pada Pemerintah Kabupaten Pasaman Barat. Humanus 10, 52 61.

Harahap, Z. A. A. (2014). Konsep Maqasid Al-Syariah sebagai Dasar Penetapan dan Penerapannya Dalam Hukum Islam Menurut Izzuddin bin Abd Al-Salam (w. 660 H). TAZKIR: Jurnal Penelitian Ilmu-ilmu Sosial dan Keislaman 9.

Huda (2018). The World's Muslim Population. : https://www.thoughtco.com/worldsmuslim-population-2004480? utm $_{s}$ ource $=$ emailshareutm edium $_{m}$ = socialutm ampaign $=$ shareurlbuttons

Karim, P. A. (2017). Memanai Syahadatain dan Keutamaannya dalam Kehidupan. Nizhamiyah 7.

Majid, N. (2000). Kehampaan spiritual masyarakat modern, respon dan transformasi nilai-nilai Islam menuju masyarakat madani. Mediacita . (ed.).
Nugroho, L. (2017). Kompasiana. https://www.kompasiana.com/lukelucky38/587c2e02d37a61570f21 wisata-halal-dan-daya-saing-pariwisata-indonesia.

Nugroho, L. and Husnadi, T. C. (2017). Maslahah and Strategy to Establish a Single State-Owned Islamic Bank in Indonesia. Tazkia Islamic Finance and Business Review $10,1-1$.

Nugroho, L. et al. (2017). The Urgency of Allignment Islamic Bank to Increasing the Outreach (Indonesia Evidence). International Journal of Economics and Financial Issues 7.

Pearce, J. A., Robinson, R. B., and Subramanian, R. (2000). Strategic management: Formulation, implementation, and control, ., I.-H. (ed.) (Columbus, $\mathrm{OH}$ ).

Porter, M. (1996).

Porter, M. E. and Gibbs, M. I. (2001).

Seddon, P. and Lewis, G. (2003). Strategy and business models: what's the difference? Proceedings, 17-17. PACIS.

Sudiarta, I. N. (2018). Cruise Tourism: Persaingan Image, Values Dan Branding Destinasi Wisata. Jurnal Ilmiah Hospitality Management 2.

Sukmadilaga, C. and Nugroho, L. (????). Pengantar Akuntansi Perbankan Syariah.

Widagdyo, K. G. (2015). Analisis pasar pariwisata halal indonesia. Tauhidinomics 1, 73-80.

uhdi, M. and Harfin (2017). Fundamentalisme dan Upaya Deradikalisasi Pemahaman Al-Quran Dan Hadis. RELIGIA.

Conflict of Interest Statement: The authors declare that the research was conducted in the absence of any commercial or financial relationships that could be construed as a potential conflict of interest.

Copyright (c) 2019 Nugroho, Utami and Meiwanto Doktoralina. This is an open-access article distributed under the terms of the Creative Commons Attribution License (CC $B Y)$. The use, distribution or reproduction in other forums is permitted, provided the original author(s) and the copyright owner(s) are credited and that the original publication in this journal is cited, in accordance with accepted academic practice. No use, distribution or reproduction is permitted which does not comply with these terms. 


\section{LIST OF FIGURES}

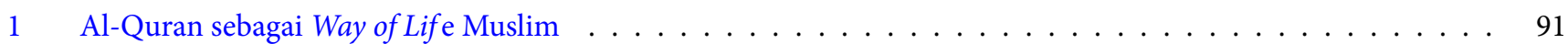

2 Wisatawan mancanegara yang datang ke Indonesia . . . . . . . . . . . . . . . . . . . . 92 


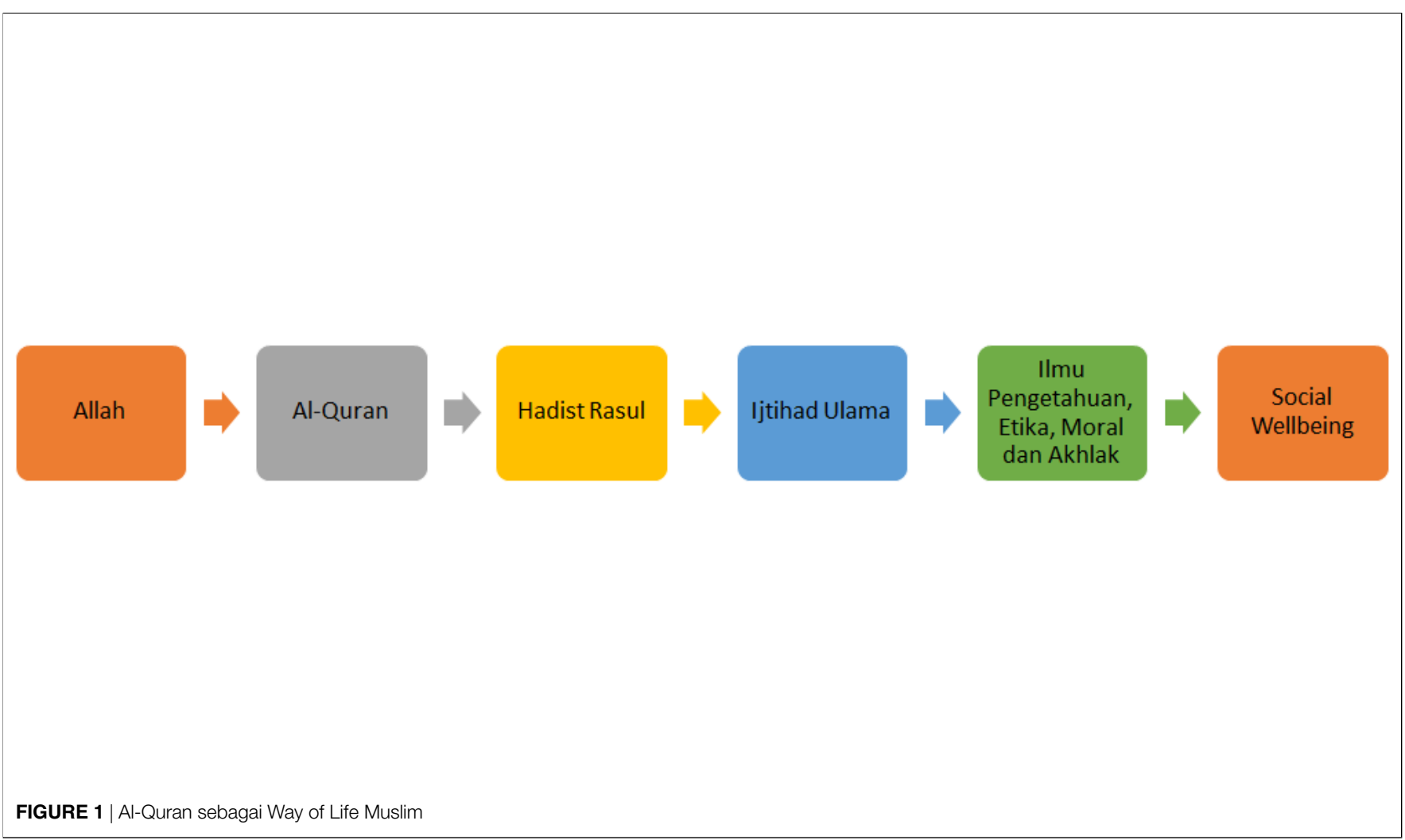




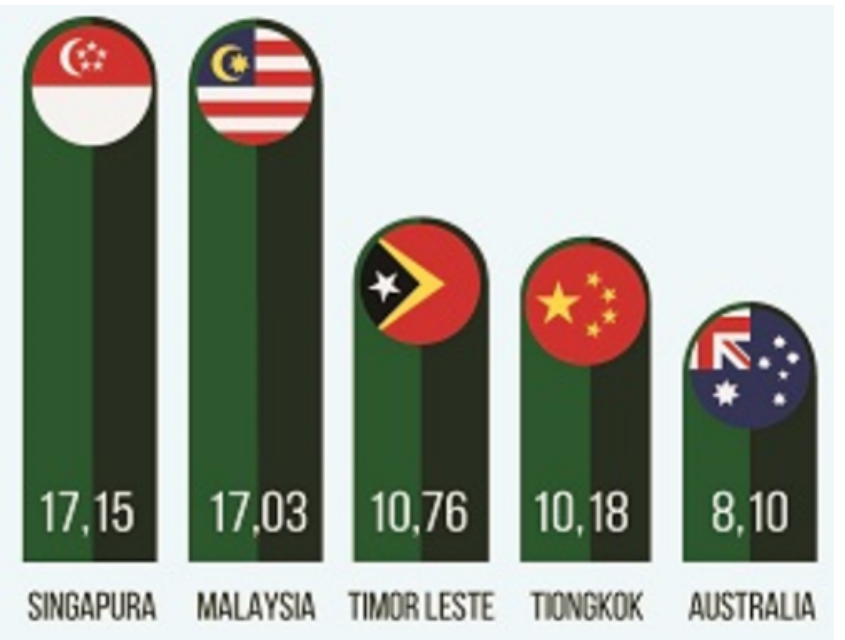

FIGURE 2 | Wisatawan mancanegara yang datang ke Indonesia 